\title{
EFFECT OF POTASSIUM NITRATE ON THE PRODUCTION OF RICININE BY Ricinus communis AND ITS INSECTICIDAL ACTIVITY AGAINST Spodoptera frugiperda
}

\section{EFECTO DE NITRATO DE POTASIO EN LA PRODUCCIÓN DE RICININA POR Ricinus communis Y SU ACTIVIDAD INSECTICIDA CONTRA Spodoptera frugiperda}

\author{
Antonio Flores-Macías', Gilberto Vela-Correa', Ma. de Lourdes Rodríguez-Gamiño', Yasmin Akhtar², \\ Rodolfo Figueroa-Brito ${ }^{3}$, Víctor Pérez-Moreno ${ }^{4}$, Miguel A. Rico-Rodríguez ${ }^{4}$ y Miguel A. Ramos-López ${ }^{4}$ *
}

\begin{abstract}
'Universidad Autónoma Metropolitana, Unidad Xochimilco. Calzada del Hueso 1100. 04960, Col. Villa Quietud, México D.F. ${ }^{2}$ University of British Columbia, Land and Food Systems, 2357 Main Mall Vancouver, BC, CAN V6T 1Z4, Vancouver, Canada. ${ }^{3}$ Centro de Desarrollo de Productos Bióticos, Instituto Politécnico Nacional. km 6 Carr. Yautepec-Jojutla, 62731. Calle Ceprobi No. 6, San Isidro, Yautepec, Morelos, México. ${ }^{4}$ Facultad de Química, Universidad Autónoma de Querétaro, Cerro de las Campanas s/n. 76010, Col. Las Campanas, Santiago de Querétaro, Querétaro, México.
\end{abstract}

*Corresponding author. (agromyke@yahoo.com)

\section{SUMMARY}

The effect of four nitrogen levels $\left(\mathrm{KNO}_{3}: 5,10,15\right.$ and $\left.20 \mathrm{meq} \mathrm{L}^{-1}\right)$ on the production of ricinine was studied using a semi-hydroponic system. The insecticidal activity of methanolic extracts of Ricinus communis L. leaves against Spodoptera frugiperda Smith larvae was also tested. A dosage response relationship showed strong positive correlation $\left(R^{2}=0.92, P \leq\right.$ $0.05)$ between the nitrogen concentration in the hydroponic solution and ricinine percentage in leaves. A strong correlation $\left(R^{2}=0.94, P \leq 0.05\right)$ was also shown for nitrogen content in tissues and ricinine percentage. The use of nitrogen in the form of $\mathrm{KNO}_{3}$ increased the production of ricinine, and it also affected mortality of $S$. frugiperda larvae. $\mathrm{LC}_{50}$ for ricine methanolic extracts of $R$. communis leaves on $S$. frugiperda were $13,469.12,15,754.34$, $16,046.11$ and $18,155.75 \mathrm{mg} \mathrm{mL}^{-1}$ for nitrogen concentrations of $20,15,10$ and 5 meq L $^{-1}$ respectively. Increased nitrogen concentration in the hydroponic solution associated with increments in leaf area and ricinine concentration. This indicates that nitrogen concentration can be manipulated to improve production of this alkaloid, and the extracts used for crop protection.

Index words: Ricinus communis, Spodoptera frugiperda, hydroponic solution, nitrogen, ricinine.

\section{RESUMEN}

En este estudio se evaluó el efecto de cuatro niveles de nitrato de potasio $\left(\mathrm{KNO}_{3}: 5,10,15\right.$ y 20 meq $\left.\mathrm{L}^{-1}\right)$ en la producción de ricinina mediante un sistema semi-hidropónico, y la actividad insecticida del extracto metanólico obtenido de hojas de Ricinus communis L contra larvas de Spodoptera frugiperda Smith. El extracto metanólico se usó para la obtención del alcaloide, y con él se evaluó su actividad biológica contra larvas de $\mathrm{S}$. frugiperda. La relación dosis/respuesta demostró una alta correlación positiva $\left(R^{2}=0.92\right.$, $P \leq 0.05$ ) entre la concentración de nitrógeno en la solución hidropónica y el porcentaje de ricinina en las hojas. Lo mismo se observó $R^{2}=0.94, P \leq$ 0.05 ) entre el contenido de nitrógeno foliar y el porcentaje de ricinina. El uso de KNO3 como fuente nitrogenada incrementó la producción de ricinina y también afectó la mortalidad larval de $S$. frugiperda. $L a s \mathrm{LC}_{50}$ determinadas para S. frugiperda fueron de $13,469.12,15,754.34,16,046.11$ y $18,155.75 \mathrm{mg}$ $\mathrm{mL}^{-1}$ para los extractos metanólicos obtenidos de hojas de plantas crecidas en las concentraciones de nitrógeno de $20,15,10$ and $5 \mathrm{meq} \mathrm{L}^{-1}$ respectivamente. El incremento en la concentración de ricinina al aumentar la concentración de nitrógeno en la solución hidropónica al indica que esta técnica puede utilizarse para mejorar la producción de este alcaloide y con ello elevar su capacidad de protección contra S. frugiperda.
Palabras clave: Ricinus communis, Spodoptera frugiperda, solución hidropónica, nitrógeno, ricinina.

\section{INTRODUCTION}

The composition of primary and secondary metabolites in plants depends on a combination of genetic factors and growth conditions. External factors such as nutrient levels, light, growth regulators and water stress can easily alter synthesis routes of secondary metabolites (Traw and Ackerly, 1995; Ramachandra and Ravishankar, 2002).

The effect of nutritional levels on the production of secondary metabolites has been previously studied, particularly nitrogen and its application, in producing cellular level of alkaloids (Abdolzadeh et al., 2006; Hussain et al., 2012; Ziba et al., 2011). However, the effect of different hydroponic nitrogen levels on the induction to produce secondary metabolites in plant has not been reported (Gontier et al., 2002).

Many secondary metabolites found in plants play a significant role in plant protection against insect pest and pathogens. These defensive roles act by influencing the behavior, growth, or survival of herbivores, and they may include feeding and oviposition deterrent effects, repellent and toxic effects. Several plant families have been reported to have insecticidal properties, such as Euphorbiaceae, Asteraceae, Lamiaceae, Fabaceae, Solanaceae and Meliaceae (García-Mateos et al., 2004).

Castor bean (Ricinus communis L., Euphorbiaceae) has been investigated for its drying properties, medicinal and insecticidal effects (Rodríguez-Hernández, 2005). Ricinine (3-Cyano-4 methoxy-N-methyl-2-pyridone) is an alkaloid present in castor bean plants (Wang et al., 2009), which 
has insecticidal, acaricidal and nematicidal activities (Bigi et al., 2004; Bharadwaj and Sharma, 2007; Ramos-López et al., 2010; Bullangpoti et al., 2011), and whose production can be enhanced by nitrogen (Waller y Yang, 1965).

An important agricultural pest, the fall armyworm Spodoptera frugiperda (Lepidoptera: Noctuidae) larvae, is an insect species that displays a very wide host-plant range including 80 plant species across 23 families (Pashley, 1988). However, S. frugiperda has shown resistance to synthetic insecticides (Sayyed et al., 2008), then pointing out the need to develop new control methods, most particularly methods based on plant derived compounds with low impact on the environment and human health.

The aim of this study was to evaluate the effect of different nitrogen levels in a semi-hydroponic system on leaf growth, tissue nitrogen content and production of ricinine, and its subsequent role in crop protection. We tested the insecticidal effect of the methanolic extract of R. communis leaves containing different nitrogen contents against Spodoptera frugiperda larvae.

\section{MATERIALS AND METHODS}

This work was carried out at the Laboratory of Physiology and Technology of Crops and Center of Biological Research and Aquaculture Cuemanco (CIBAC) of Universidad Autónoma Metropolitana Unidad Xochimilco, and at the Insecticide Natural Compounds Laboratory of Universidad Autónoma de Querétaro, México, from January 2012 to June 2013.

\section{Plant material}

Seeds of R. communis were collected from plants located in the south of México City, (190 18’ 54.6 N; $99^{\circ} 05^{\prime} 59.9$ $\mathrm{W})$. The taxonomic authentication was performed by $\mathrm{M}$. Sc. Patricia Zavaleta Beckler, and a voucher specimen was stored in the Herbarium of Universidad Autónoma Metropolitana Unidad Xochimilco (UAM-X 4626).

\section{Plant growth}

The seeds were germinated on peat moss $100 \%$ as substrate, and the resulting seedlings were transplanted $25 \mathrm{~d}$ after emergency into polyethylene pots containing 15 $\mathrm{L}$ of substrate grounded red volcanic rock with particle size of 0.5 to $1.5 \mathrm{~cm}$, previously disinfected with $1 \%$ sodium hypochlorite solution. The plants were established under greenhouse conditions in semi-hydroponic production system containing four nitrogen concentrations $(5,10,15$ and 20 meq $\mathrm{L}^{-1}$ ), as treatments. For this semi-hydroponic assay treatments were distributed in a completely rando- mized design with four replicates. The greenhouse conditions were monitored using a Hobo H21-001 climatologic station.

The nitrogen concentrations were formulated based on the nutrient solution according to Steiner (1961), and prepared with reagent grade salts, acidified with $1 \mathrm{~N} \mathrm{H}_{2} \mathrm{SO}_{4}$ to $\mathrm{pH}$ of 5.5. Nutrients provided included potassium nitrate, calcium sulfate, monopotassium phosphate, magnesium sulfate and potassium sulfate, and $1 \mathrm{~L}$ of the prepared solution contained iron sulfate (198 g), sulfate magnesium (81 g), zinc sulfate (44 g), copper sulfate (8 g) and borax $(43 \mathrm{~g})$. These solutions were applied using an automated drip irrigation system $\left(2 \mathrm{~L} \mathrm{~h}^{-1}\right)$ which supplied $150 \mathrm{~mL} \mathrm{~d}^{-1}$ of solution per plant for $30 \mathrm{~d}$, and thereafter $250 \mathrm{~mL} \mathrm{~d}^{-1}$ until harvest.

At $60 \mathrm{~d}$ after the transplant all the leaves were harvested and leaf area quantified with a leaf area meter (Li-Cor Li -3100; Lincoln, NE, USA), and the N concentration was quantified by the Micro-Kjeldahl method (Guebel et al., 1991).

The average temperature during the experiment was 21.2 ${ }^{\circ} \mathrm{C}$; the highest temperature was $49.0^{\circ} \mathrm{C}$ and the minimum temperature was $8.2^{\circ} \mathrm{C}$. The relative average humidity was $74.1 \%$; with maximum humidity observed at sunset (after 18:00 $\mathrm{h}$ ) and sunrise (0600-0800 h), while the minimum humidity occurred close to $14: 00 \mathrm{~h}$ when the maximum average solar radiation $\left(830.6 \mathrm{Wm}^{-2}\right.$ ) also occurred.

\section{Methanol extract of ricinine from aerial parts of $R$. communis}

Dried aerial parts of $R$. communis (300 g) were grounded to a powder, and $50 \mathrm{~g}$ were placed in an Erlenmeyer flask and soaked in $150 \mathrm{~mL}$ of methanol with intermittent shaking for $24 \mathrm{~h}$ at room temperature. The extract was filtered through a Buchner funnel with Whatman number 1 filter paper. The resulting solution was concentrated by reduced pressure in a rotary evaporator at $35^{\circ} \mathrm{C}$ and stored at $4{ }^{\circ} \mathrm{C}$ in a refrigerator until use. The obtained extracts were analyzed by HPLC to quantified extract ricinine.

\section{HPLC analysis}

Samples of ricinine standards and methanolic extracts were analyzed in triplicate by High Performance Liquid Chromatography (HPLC) (Varian StarPro335), equipped with a C18 column in reverse phase $(250 \times 4.6 \mathrm{~mm}$ and $5 \mu \mathrm{m}$ particle size) (Grace). The water and the methanol used were HPLC grade (Caledon) and reference compound ricinine (Latoxan, France) was used. The equipment was

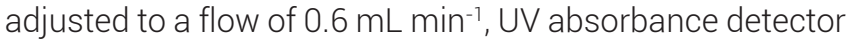


was set at $250 \mathrm{~nm}$, ratio methanol: water was $75: 25 \%$, and the running time per sample was $20 \mathrm{~min}$.

The calibration curve was done by triplicate in HPLC, using a series of concentrations (2.0, 0.2, 0.02, 0.002 and $0.0002 \mathrm{mg} \mathrm{mL}^{-1}$ ) of standard ricinine and the corresponding area under the curve. The ricinine content in each methanolic extract (RME) was calculated with the formulae:

$$
R M E=A U C M E \times C S R / A U C S R
$$

Where: $A \cup C M E$ = area under the curve from methanolic extract at $2 \mathrm{mg} \mathrm{mL}^{-1} ; \mathrm{CSR}=$ concentration of standard ricinine $\left(2 \mathrm{mg} \mathrm{mL}^{-1}\right) ; A U C S R$ = area under the curve of standard ricinine at $2 \mathrm{mg} \mathrm{mL}^{-1}$.

\section{Bioassay}

The methanolic extracts from leaves of $R$. communis were evaluated for their insecticidal activity on first instar larvae of S. frugiperda growing on the artificial diet proposed by Bergvinson and Kumar (1997).

A preliminary test was performed to evaluate five concentrations varying between $24 \times 10^{3}$ and $0.16 \times 10^{3} \mathrm{mg}$ $\mathrm{mL}^{-1}$, each added to the diet before culture medium solidification. Larval mortality was assessed 15 days after the insects were put into the treatments, according to a modified method used by Rodríguez-Hernández and Vendramim (1996). This experiment allowed to determine the minimum and maximum concentrations affecting larval mortality.

The subsequent testing concentrations $\left(24 \times 10^{3}, 16 \times\right.$ $10^{3}, 9.6 \times 10^{3}, 4.0 \times 10^{3}$, and $1.6 \times 10^{3} \mathrm{mg} \mathrm{mL}^{-1}$ ) looking for a strong correlation between concentration and mortality. One $\mathrm{mL}$ of each mixed treatment diet was poured into $28.3 \mathrm{~g}$ acrylic vessels (Bio-Serv No. 9051) with 24 replicates per treatment, prior to the medium solidification at room temperature for $24 \mathrm{~h}$. Thereafter, a first instar larva of $S$. frugiperda was placed into each compartment and covered with a white cardboard adjustable lid (Bio-Serv No. 9049). The vessels were then randomly placed $\mathrm{n}$ a growth chamber set at $27 \pm 2{ }^{\circ} \mathrm{C}, 70 \% \pm 5 \% \mathrm{RH}$, and $14 / 10 \mathrm{~h}$ light/ dark cycles, according the methodology reported by PérezGutiérrez et al. (2011).

\section{Statistical data analysis}

The collected data were tested for normality (ShapiroWilk W test) and homocedasticity (Bartlett test). The Kruskal-Wallis non-parametric analysis of variance was used when data violated the normality assumption and could not be corrected using a transformation. One way ANOVA analysis and Tukey test $(P<0.05)$ were also performed for mortality data at different concentrations of each extract. Linear regression analysis was used for quantifying the relationship between tissue nitrogen-concentration and $\mathrm{N}$ concentration in nutrient solution, and between tnitrogen concentration and ricinine content in leaf tissue. The $\mathrm{LC}_{50}$ (concentration causing $50 \%$ mortality compared to the control) was calculated for each treatment by the probit analysis, based on the percent of mortality obtained at each concentration of the samples, using the Systat 8.0 statistical analysis program (SPSS Inc., 1998).

\section{RESULTS}

\section{Nitrogen content in leaf tissue}

The nitrogen content in leaf tissue showed a gradual increase with the increasing concentration of nitrogen in the hydroponic solution $\left(R^{2}=0.97, P \leq 0.05\right)$, demonstrating a significant difference between treatments $5(F=0.049)$ and 10 meq $\mathrm{L}^{-1}(\mathrm{~F}=0.79)$ and treatments 15 and 20 meq $\mathrm{L}^{-1}$ (Figure 1). There was also a significant increase in leaf area with increasing nitrogen accumulation in tissue, as demonstrated by the slope of the regression curve $\left(R^{2}=\right.$ $0.71 ; P \leq 0.05$ ) (Figure 2).

\section{Correlation between nitrogen content in leaf tissue and ricinine production}

The chromatograms of standard ricinine curve exhibited a linearity and high correlation of nitrogen $\left(R^{2}=0.992 ; \mathrm{P}\right.$ $\leq 0.05$ ), since ricinine concentrations were $0.0894,0.101$, 0.103 and $0.1042 \mathrm{mg} \mathrm{mL}^{-1}$ for the 5, 10, 15 and 20 meq $\mathrm{L}^{-1}$ potassium nitrate solutions, respectively. The ricinine synthesized in the foliage of $R$. communis grown at 5 meq $\mathrm{L}^{-1}$ of $\mathrm{N}$ solution, was significantly less as compared with higher $\mathrm{N}$ concentrations.

The results also show a significant increase in leaf area in response to an increasing amount of nitrogen in the hydroponic solution. There is also a positive correlation $\left(R^{2}=\right.$ $0.94 ; \mathrm{P} \leq 0.05$ ) between the content of ricinine in leaf tissue and the nitrogen content in the hydroponic solution (Figure 3). A positive correlation $\left(R^{2}=0.92, P \leq 0.05\right)$ was also observed in the content of ricinine associated with increase in nitrogen leaf tissue (Figure 4).

\section{Mortality assay}

Mortalities differed among different concentrations (24 $\times 10^{3}, 16 \times 10^{3}, 9.6 \times 10^{3}, 4.0 \times 10^{3}$ and $1.6 \times 10^{3} \mathrm{mg} \mathrm{mL}$ $\left.{ }^{1}\right)$ of the methanolic extract of $R$. communis (Table 1) at varying nitrogen content. The lowest $\mathrm{LC}_{50}\left(13.469 \times 10^{3}\right.$ $\mathrm{mg} \mathrm{mL}^{-1}$ ) was observed with the extract containing the 


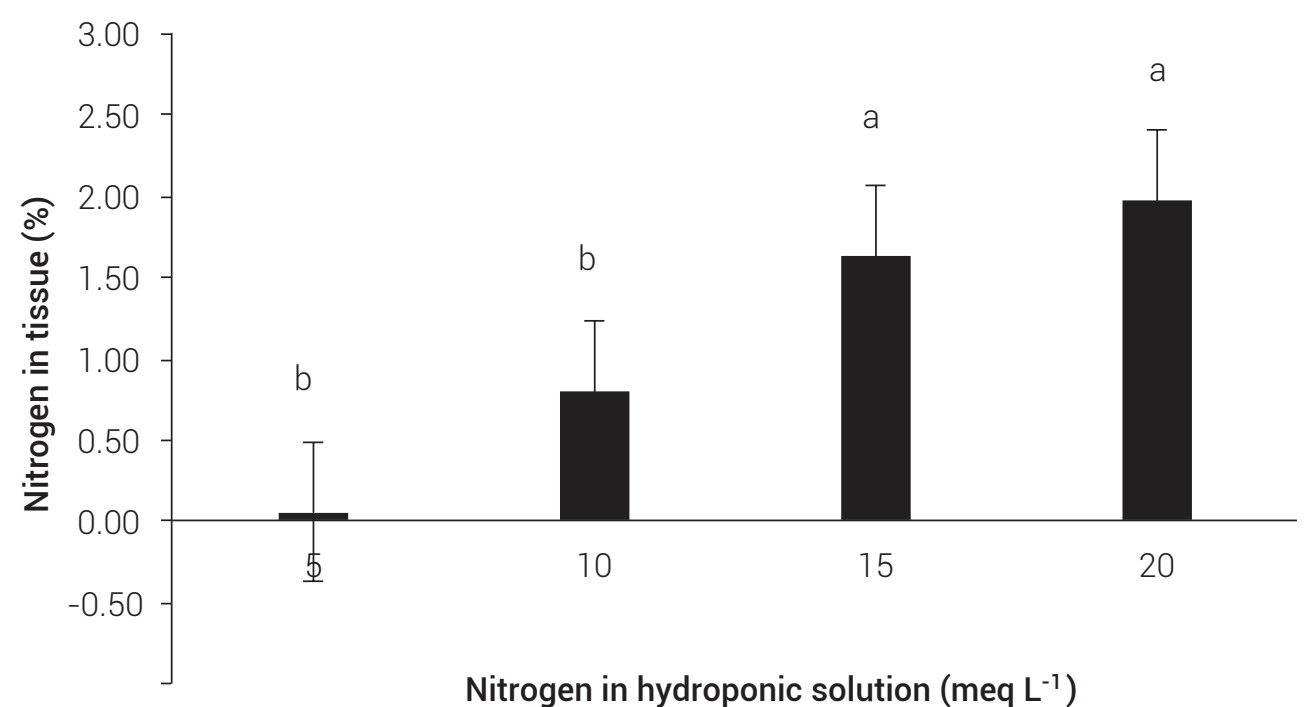

Figure 1. Mean values for nitrogen content in leaf tissue for plants growing at different nitrogen concentrations in hydroponic solution. Different letters indicate significantly different means (Tukey, $0.05 ; n=4$ ).

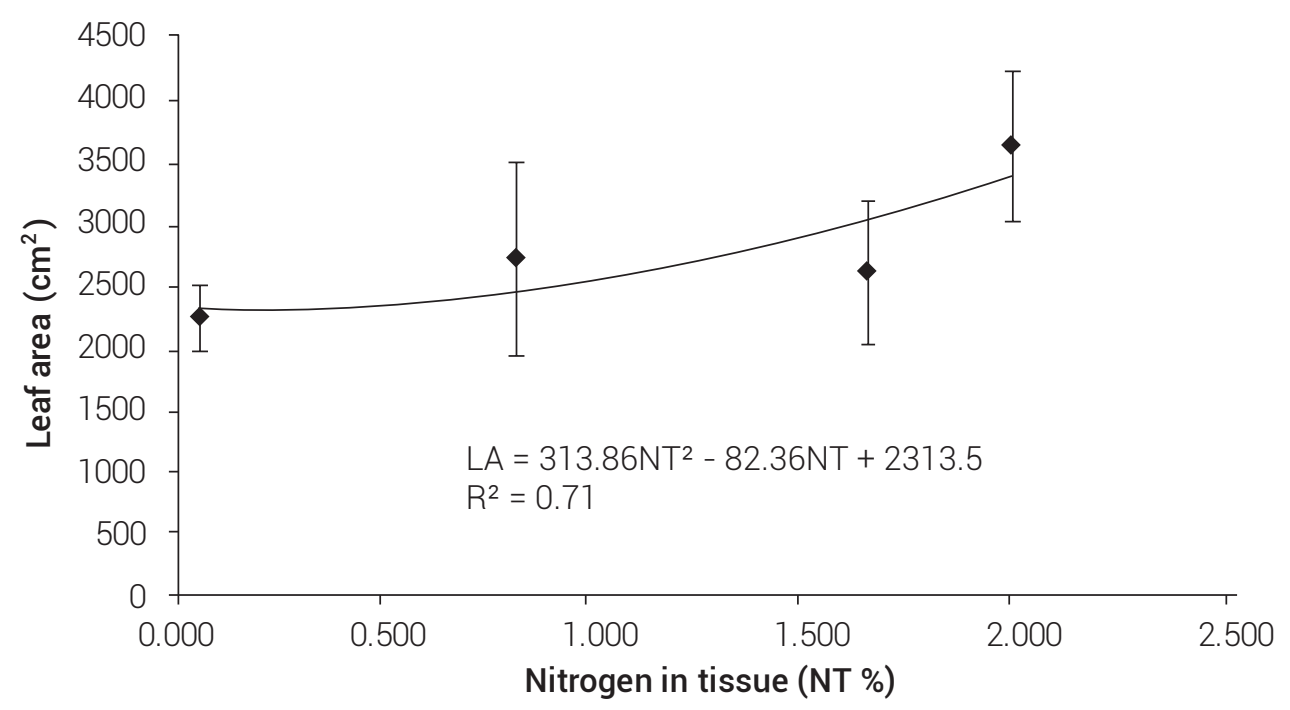

Figure 2. Relationship between leaf area (LA) and nitrogen content in leaf tissue ( $n=4$; $P \leq 0.05)$.

highest nitrogen content ( 20 meq $\left.\mathrm{L}^{-1}\right)$, followed by the extracts containing $15 \mathrm{meq} \mathrm{L}^{-1}\left(\mathrm{LC}_{50}=15.754 \times 10^{3}\right), 10 \mathrm{meq}$ $\mathrm{L}^{-1}\left(\mathrm{LC}_{50}=16.046 \times 10^{3}\right)$ and $5 \mathrm{meq} \mathrm{L}^{-1}\left(\mathrm{LC}_{50}=18.156 \times 10^{3}\right.$ $\left.\mathrm{mg} \mathrm{mL}^{-1}\right)$ for nitrogen content.

\section{DISCUSSION}

The results of nitrogen content in leaf tissue showed in this study are consistent with those reported by Gontier et al. (2011) whom demonstrating gains in leaf area, specific leaf weight and chlorophyll content when increasing nitro- gen applications. Cramer et al. (2000), who studied the response of tree canopy to nitrogen applications, also found a significant increase in leaf $\mathrm{N}$ concentration in response to higher doses of $\mathrm{N}$ in the nutrient solution, for most of the species studied.

It has been demonstrated that the secondary metabolites of hydroponic grown plants of Datura and Taxus can be 'milked' using hydroponic conditions and permeabilization (Gontier et al., 2002). In plants of Acmella oleraceae L (Asteraceae) growing in hydroponics, Abeysinghe et al. (2014) 


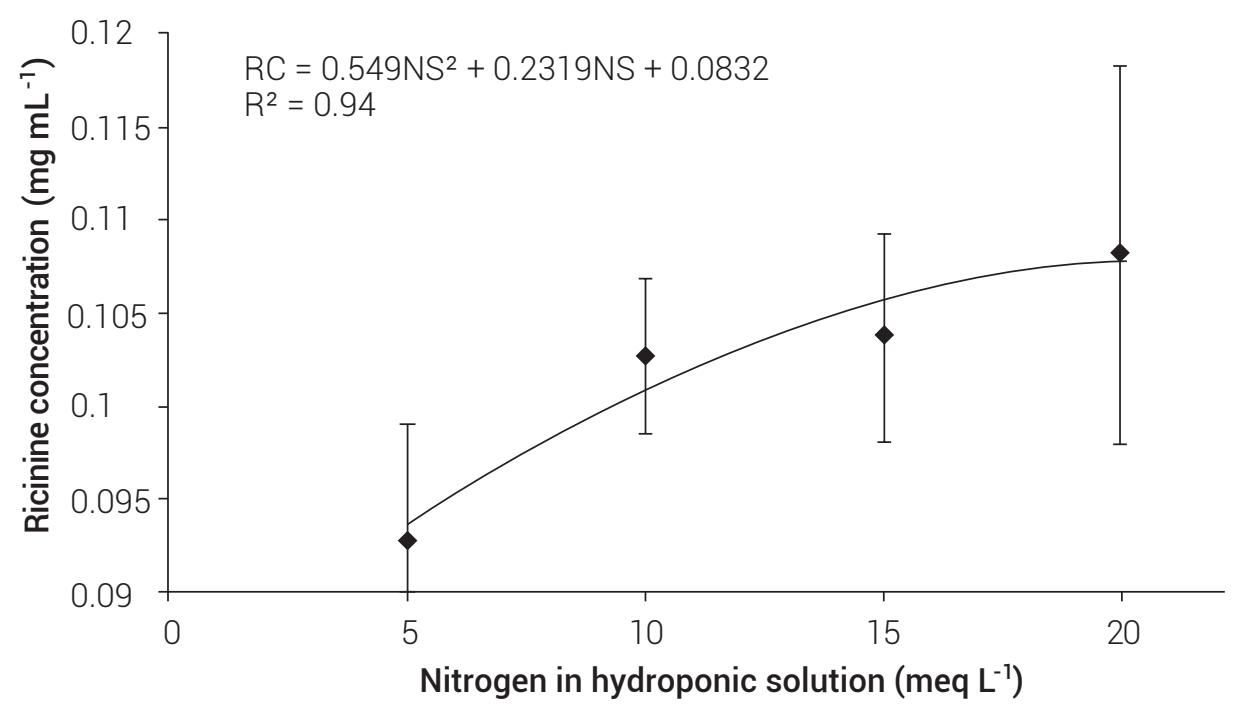

Figure 3. Relationship between ricinine concentration in the leaf and nitrogen content in the hydroponic solution $(n=4 ; P \leq 0.05)$.

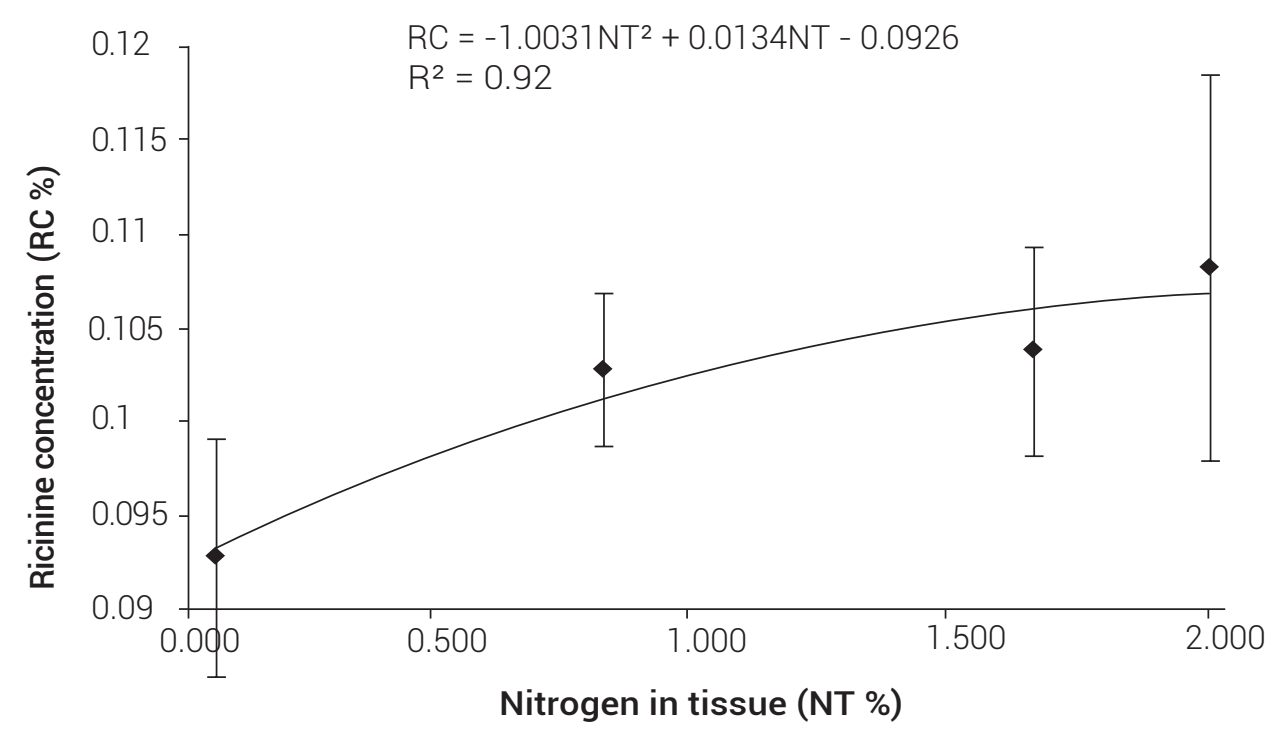

Figure 4. Relationship between ricinine concentration and nitrogen content, both in the leaf tissue $(n=4 ; P \leq 0.05)$.

were able to increase the total phenolics and flavonoids contents by supplying more $\mathrm{N}$ to the nutrient solution.

Waller and Henderson (1961) and Waller and Yang (1965), who studied the biosynthetic pathway of ricinine from organic and inorganic compounds labeled with $\mathrm{N}^{15}$, found that the relative efficiency of incorporation of labeled compounds followed a gradient: formamide glutamine aspartate $>>>\mathrm{NH}_{4} \mathrm{NO}_{3}$ nicotinamide (Amida- $\mathrm{N}$ ) $>>$ nicotinitrile $\mathrm{KNO}_{3}$ (nitrile-N) 1-methyinicotinamida > (Amide- $\mathrm{N}$ ) 1-methyilnicotinonitrilo $>$ (nitrile $\mathrm{N}$ ). These results indicate that the soluble nitrogenous fertilizer $\left(\mathrm{KNO}_{3}\right)$ of the nutrient solution is an efficient source of precursor in the produc- tion of ricinine. However, nitrogen supplied in the form $\mathrm{NH}^{-}$ ${ }_{4} \mathrm{NO}_{3}$ reaches higher incorporation efficiency than the $\mathrm{KNO}_{3}$ used in this experiment; there could be also a higher induction of ricinine production.

On the other hand, it has been previously shown that the ammonium/nitrate-nitrogen ratio and overall levels of total nitrogen markedly affect the production of secondary plant products (Ramachandra and Ravishankar, 2002; Sae-Lee et al., 2014). In our research noted that the ricinine content in leaf tended to increase as the level of nitrogen leaf concentration raised. 
Table 1. Average ( \pm se) larval mortality of $S$. frugiperda caused by methanolic leaf extracts of $R$. communis from plants growing at different nitrogen concentrations in the hydroponic solution.

\begin{tabular}{lcccc}
\hline $\begin{array}{l}\text { N concentration } \\
\left(\mathrm{mg} \mathrm{mL}^{-1}\right)\end{array}$ & 20 meq L-1 & $15 \mathrm{meq} \mathrm{L}^{-1}$ & $10 \mathrm{meq} \mathrm{L}$ & $5 \mathrm{meq} \mathrm{L}^{-1}$ \\
\hline 24,000 & $87.5 \pm 2.9 *$ & $79.2 \pm 2.9 *$ & $79.2 \pm 2.9 *$ & $75 \pm 3.7 *$ \\
16,000 & $54.2 \pm 4.0 *$ & $41.7 \pm 4.6 *$ & $41.7 \pm 4.6 *$ & $33.3 \pm 3.7 *$ \\
9600 & $37.5 \pm 4.0 *$ & $37.5 \pm 2.9 *$ & $33.3 \pm 3.7 *$ & $25 \pm 3.1 *$ \\
4000 & $25 \pm 4.6 *$ & $20.8 \pm 2.9 *$ & $16.7 \pm 3.7 *$ & $8.3 \pm 3.1$ \\
1600 & $8.3 \pm 3.1$ & $4.2 \pm 2.9$ & $8.3 \pm 3.1$ & $4.2 \pm 2.9$ \\
0 & $4.2 \pm 2.9$ & $4.2 \pm 2.9$ & $4.2 \pm 2.9$ & $4.2 \pm 2.9$ \\
& 13.46912 & 15.75434 & 16.04611 & 18.15575 \\
$\mathrm{LC}_{50}$ & $(11.12145-16.44106) \times$ & $(13.08424-19.47266) \times$ & $(13.33269-19.87345) \times$ & $(15.36153-22.25480) \times$ \\
& $10^{3} \mathrm{mg} \mathrm{mL}^{-1}$ & $10^{3} \mathrm{mg} \mathrm{mL}^{-1}$ & $10^{3} \mathrm{mg} \mathrm{mL}^{-1}$ & $10^{3} \mathrm{mg} \mathrm{mL}^{-1}$ \\
\hline
\end{tabular}

* Significant differences respect to control $(n=24 ; P \leq 0.05)$.

According to Ramos-López et al. (2010) the mortality of $S$. frugiperda larvae caused by methanolic leaf extracts from $R$. communis estimated by the Viability Larvae Concentration $50\left(\mathrm{LC}_{50}\right)$ was $5.07 \times 10^{3} \mathrm{mg} \mathrm{mL}^{-1}$ for the leaf extract and $0.38 \times 10^{3} \mathrm{mg} \mathrm{mL}^{-1}$ for the ricinine standard. With these results they demonstrated for the first time that ricinine is an active ingredient of $R$. communis that acts against S. frugiperda.

In our research the obtained $\mathrm{VLC}_{50}$ values were higher for the same extract but when the ricinine concentration was highest the larval mortality was highest too, corroborating that this alkaloid is the principal insecticide active ingredient of this plant. This alkaloid has also shown activity against other insects as Atta sexdens rubropilosa Forel (Hymenoptera: Formicidae) (Bigi et al., 2004) and Spodoptera exigua Hübner (Lepidoptera: Noctuidae) (Bullangpoti et al., 2011).

\section{CONCLUSIONS}

By increasing the $\mathrm{N}$ concentration in hydroponic solution significant gains in leaf area of $R$. communis can be obtained, which would be directly proportional to the amount of ricinine in the leaf methanol.

There is also a positive and significant correlation between the concentration of ricinine in leaf extracts of $R$. communis and their insecticidal activity against $S$. frugiperda larvae.

\section{BIBLIOGRAPHY}

Abdolzadeh A., F. Hosseinian, M. Aghdasi and H. Sadgipoor (2006) Effect of nitrogen sources and levels on growth and alkaloid contents of periwinkle. Asian Journal of Plant Sciences 5:271-276.

Abeysinghe D. C., S. M. N. K. Wijerathne and R. M. Dharmadasa (2014) Sec- ondary metabolites contents and antioxidant capacities of Acmella olaraceae grown under different growing systems. World Journal of Agricultural Research 2:163-167.

Bergvinson D. J. and H. Kumar (1997) Cría masiva de insectos en el laboratorio de entomología del CIMMYT (Diatraea grandiosella, SWCB; Diatraea saccharalis, SBC; Spodoptera frugiperda, FAW y Helicoverpa zea, CEW). In: Annual Research Progress Report 1996, Maize Entomology. Apéndice 7. CIMMYT, México.

Bharadwaj A. and S. Sharma (2007) Effect of some plant extracts on the hatch of Meloidogyne incognita egss. International Journal of Botany 3:313-316.

Bigi M. F., L. V. Vera, S. T. Groote, M. J. Bueno, A. H. Pagnocca, F. C. Fernandes, P. C. Vieira and M. F. Silva (2004) Activity of Ricinus communis (Euphorbiaceae) and ricinine against the leaf-cutting ant Atta sexdens rubropilosa (Hymenoptera: Formicidae) and the symbiotic fungus Leucoagaricus gongylophorus. Pest Management Science 60:933-938.

Bullangpoti V., N. Khumrungsee, W. Pluempanupat, Y. Kainoh and U. Saguanpong (2011) Toxicity of ethyl acetate extract and ricinine from Jatropha gossypifolia senecent leaves against Spodoptera exigua Hübner (Lepidoptera: Noctuidae). Journal of Pesticide Science 36:260-263.

Cramer J., T. Fahey and J. Battles (2000) Patterns of leaf mass, area and nitrogen in young northern hardwood forests. The American Midland Naturalist 144:253-264.

García-Mateos R., R. Pérez-Pacheco, C. Rodríguez-Hernández y M. Soto-Hernández (2004) Toxicidad de alcaloides de Erythrina americana en larvas de mosquito Culex quinquefasciatus. Revista Fitotecnia Mexicana 27:297-303.

Gontier E., A. Clément, T. L. M. Tran, A. Gravot, K. Liévre, A. Guckert and F. Bourgaud (2002) Hydroponic combined with natural or forced root permeabilization: a promising technique for plant secondary metabolite production. Plant Science 163:723-732.

Gontier E., A. Clément, T. L. M. Tran, A. Gravot, K. Liévre, A. Guckert, M. M. A. Mondal, M. A. Rahman, M. B. Akter and M. S. A. Fakir (2011) Effect of foliar application of nitrogen and micronutrients on growth and yield in mung bean. Legume Research 34:166-171.

Guebel D. V., B. C. Nudel and A. M. Giulietti (1991) A simple and rapid micro-Kjeldahl method for total nitrogen analysis. Biotechnology Techniques 5:427-430.

Pashley D. P. (1998) Current status of fall armyworm host strains. The Florida Entomologist 71:227-234.

Pérez-Gutiérrez S., M. A. Zavala-Sánchez, M. M. González-Chávez, N. C. Cárdenas-Ortega and M. A. Ramos-López (2011) Bioactivity of Carica papaya (Caricaceae) against Spodoptera frugiperda (Lepidoptera: Noctuidae). Molecules 16:7502-7509.

Ramachandra S. R. and G. A. Ravishankar (2002) Plant cell cultures: Chemical factories of secondary metabolites. Biotechnology Advances 20:101-153. 
Ramos-López M. A., S. Pérez-Gutiérrez, C. Rodríguez-Hernández, P. GuevaraFefer and M. A. Zavala-Sánchez (2010) Activity of Ricinus communis (Euphorbiaceae) against Spodoptera frugiperda (Lepidoptera: Noctuidae). African Journal of Biotechnology 9(9): 1359-1365.

Rodríguez-Hernández C. y D. J. Vendramim (1996) Toxicidad de extractos de Meliaceae en Spodoptera frugiperda (Lepidoptera: Noctuidae). Manejo Integrado de Plagas 42:14-22.

Rodríguez-Hernández C. (2005) Plantas Contra Plagas 2: Epazote, Hierba de la Cucaracha, Paraíso, Higuerilla y Sabadilla. Colegio de Postgraduados y Red de Acción sobre Plaguicidas y Alternativas en México. México, D.F. 109 p.

Sae-Lee N., 0. Kerdchoechuen and N. Laohakunjit (2014) Enhacement of phenolics, resveratrol and antioxidant activity by nitrogent enrichment in cell suspension cultureof Vitis vinifera. Molecules 19:7901-7912.

Sayyed A. H., M. Ahmad and M. A. Saleem (2008) Cross-resistance and genetics of resistance to indoxacarb in Spodoptera litura (Lepidoptera: Noctuidae). Journal of Economic Entomology 101:472-479
SPSS Inc. (1998) SYSTAT 8.0. SPSS Inc. Chicago, IL. USA, ISBN 1-56827-222-7. $1086 \mathrm{p}$.

Steiner A. A. (1961) A universal method for preparing nutrient solution of a certain desired composition. Plant and Soil 15:134-154.

Traw M. B. and D. D. Ackerly (1995) Leaf position, light levels, and nitrogen allocation in fire species of rain forest pioneer trees. American Journal of Botany 82:1137-1143.

Waller G. R. and .L M. Henderson (1961) Biosynthesis of the pyridine ring of ricinine from succinate and other labeled compounds. Biochemical and Biophysical Research Communications 5:5-9.

Waller G. R. and K. S. Yang (1965) The origin of the nitrogen atoms of ricinine produced by Ricinus communis L. Phytochemistry 6:1637-1641.

Wang Z., D. Li, Z. Zhou, B. Li and W. Yang (2009) A simple method for screening and quantification of ricinine in feed with HPLC and LC-MS. Journal of Chromatography Sciences 47:585-588.

Ziba G., K. Hemati, H. Dorodian and Z. Bashiri-Sadr (2011) Effect of nitrogen fertilizer on yield and amount of alkaloids in periwinkle and determination of vinblastine and vincristine by HPLC and TLC Plant Science Research 3:4-9. 